\title{
Epidemiology of Sleep Disorders in the Adult Population of Delhi: A Questionnaire Based Study
}

\author{
J. C. Suri, M. K. Sen, Tulsi Adhikari
}

Department of Pulmonary, Critical Care \& Sleep Medicine, Vardhman Mahavir Medical College and Safdarjang Hospital, New Delhi, National Institute of Medical Statistics, ICMR, New Delhi.

Indian J Sleep Med 2008; 3.4, 128-137

\begin{abstract}
A questionnaire based survey was conducted to determine the prevalence of common sleeprelated disorders in the adult population of Delhi. The questionnaire used for the purposes of this study was adapted from those by Chervin and the Stanford Sleep Clinic questionnaire. A total of 4000 questionnaires were distributed of which 2774 were received back. And finally 2475 questionnaires were selected for analysis as they satisfied all criteria for acceptance. A subgroup of 200 (a number that was considered to be statistically significant) adults were randomly selected from the total pool of adults that reported snoring and were then subjected to whole night in-lab supervised polysomnography. The overall prevalence of snoring was found to be $39.5 \%$ (Males $=49.5 \%$, Females $=29 \%$ ). The overall prevalence of Sleep disordered breathing (SDB) was $4.3 \%$. Approximately $48.6 \%$ of the adult population was seen to suffer from excessive daytime sleepiness. The prevalence of symptoms suggestive of restless leg syndrome was $8.2 \%$ and was found to correlate significantly with $\mathrm{BMI}$, rising age and female gender. The overall prevalence of sleepwalking in the adult population studied was $6 \%$. The prevalence of nightmares in the adult population studied was $30.6 \%$ while bruxism was observed to be present in $9.2 \%$ of the adult population studied. Approximately $2.3 \%$ of the entire study population admitted that they consumed sleeping pills. Its use correlated significantly with rising socio-economic strata and symptoms suggestive of disorders of initiation and maintenance of sleep (DIMS). Approximately $10.7 \%$ of the study population responded affirmatively to have met with road traffic accident in the past few years and $28.1 \%$ of the adult population was observed to have complaints suggestive of disorders of initiation and maintenance of sleep. More than half the population under study was observed to be sleep-deprived (sleep time $<8$ hours per day); and $29.3 \%$ of them slept for less than seven hours. In this questionnaire-based survey, approximately $55 \%$ of the study population was observed to have some type of sleep-related disorder.
\end{abstract}

This indicates that the impact of sleep disorders on the morbidity profile of this segment of urban society is of a gigantic proportion. It also reflects the phenomenal burden of undiagnosed sleep disorders in this segment of the general population as well as its impact on social, mental, physical and economic health of the society.

Address for correspondence:

Dr. J. C. Suri

Senior Chest Physician \& Head

Dept of Pulmonary, Critical Care \& Sleep Medicine

Safdarjang Hospital, New Delhi

E-mail: jcsuri@rediffmail.com

Indian Journal of Sleep Medicine (IJSM), Vol. 3, No. 4, 2008 


\section{Introduction}

A questionnaire based survey was conducted to determine the prevalence of common sleeprelated disorders in the adult population of Delhi. The National Capital Region (NCR) is the metropolitan area of Delhi comprising cities like Faridabad, Gurgaon, Ghaziabad and Noida. The population of this region is approximately 12.8 million that resides in area of nearly $1483 \mathrm{sq} \mathrm{km}$.

\section{Material and Methods}

The study population included in this analysis comprised the parents of school-going children. The latter were randomly selected for inclusion in another study, the results of which were published earlier in the journal as a part of a family survey ${ }^{1}$. In addition to a set of two child questionnaires (one for the child and another for his/her sibling) a second set of two other adult questionnaires (be filled up by each parent) were also handed over to each child. Informed consent was duly obtained from each participant. A covering letter from the Principal Investigator that was addressed to the parents was included in the set. Two different types of schools were selected for recruitment of subjects. One type of schools catered to children from the relatively middle and upper classes of society; the other comprised children from the relatively lower and economically challenged section. This was deliberately so designed so as to cover a fairly large socio-economic cross-section of the population.

Each child was instructed to get the set of two adult questionnaires (one by the father and another by the mother of the child) filled up by his/her parents. The field investigator duly explained the procedure for filling up the questionnaire and extended all possible help in answering it. A total of 4000 questionnaires were distributed of which 2774 were received back. And finally 2475 questionnaires were selected for analysis as they satisfied all criteria for acceptance. Appropriate statistical methods were applied using SPSS software.

\section{The questionnaire}

The questionnaire used for the purposes of this study was adapted from those by Chervin and the Stanford Sleep Clinic questionnaire. ${ }^{2,19}$ It included questions pertaining to demography, any past and present medical problem, family history of snoring, sleep terror, nightmare. It also included questions pertaining to snoring, excessive daytime sleepiness (Epworth sleepiness score), sleep disordered breathing, disorders of initiation and maintenance of sleep, restless legs syndrome and sleep deprivation. The total number of questions in the questionnaire was 52 in addition to questions pertaining to past/present medical problems, if any.

A randomly selected sub-group of fifty subjects in whom any sleep disorder was diagnosed, on the basis of their response to the questionnaire, was also examined clinically in the Sleep Clinic. Sensitivity and specificity scores, compared with clinical diagnoses from the Sleep Clinic, were good for all sleep disorders namely, SDB (apnea), disorders of initiation and maintenance of sleep, restless legs, sleepwalking, sleep-bruxism and nightmares. The agreement between clinical diagnoses and questionnaire classification of sleep disorders was thus observed to be good.

\section{Interpretation}

Sleep disordered breathing (SDB) was clinically suspected if, in a subject with habitual snoring in whom breathing pauses were noticed and in whom the Epworth Sleepiness Score (ESS) was $>10$, the response to any one or more of the following questions was answered in the affirmative.

I. Tiredness during wake time.

II. Ever fallen asleep while driving or sitting idle

III. Have to wake up during night to pass urine.

A subgroup of 200 (a number that was considered to be statistically significant) adults were randomly selected from the total pool of adults that reported snoring and were then subjected to whole night in-lab supervised polysomnography (PSG) (Alice 5, Respironics, Murrysville, PA). The PSG study was conducted on snoring adults only because, (a) snoring was a high risk factor for SDB; (b) it was extremely difficult to convince a normal adult who had volunteered to respond to the questionnaire to undergo PSG. On the basis of the results obtained from this sample, the prevalence of SDB in the whole population was calculated. This method may have missed some cases of SDB who under-reported snoring. The following parameters were measured: 2 channels each for electroencepholography (EEG); electrooculography (EOG); and electromyography (EMG); 
airflow recording through nose and mouth by thermistor and nasal pressure cannula; thoracic and abdominal efforts by plethysmography; oxygen saturation through pulse oximetery; and tracheal sound recording by using a microphone attached to the neck.

Obstructive apnea was defined as cessation of airflow at the nose and mouth, as measured by thermistor/ nasal cannula while the respiratory effort continues for at least ten seconds. Excessive daytime sleepiness (EDS) was scored in the presence of questionnaire response of excessive daytime sleepiness along with Epworth Sleepiness Score (ESS) of $\geq 10$. Hypopnea was scored when the nasal pressure signal excursions dropped by $\geq 50 \%$ of the baseline for a duration of at least 10 seconds and was associated with a drop of saturation of $\geq 3 \%$ from the pre-event baseline or if it was associated with arousal $^{27}$ Respiratory effort related arousal (RERA) was scored when there was a sequence of breaths lasting at least ten seconds characterized by increasing respiratory effort or flattening of the nasal pressure waveform, leading to an arousal from sleep when the sequence of breaths did not meet the criteria for an apnea or hypopnea. ${ }^{27}$ SDB was diagnosed when a patient with symptoms suggesting SDB has an RDI (apneas + hypopneas + RERAs) was $>5$ per hour. Snoring adults with RDI of less than or equal to five hours of total sleep time (TST) with no clinically significant hypoxemia, hypercapnia or excessive daytime sleepiness were considered to have primary snoring 3 . The diagnosis of other sleep disorders (such as restless leg syndrome, bruxism, nightmare, sleepwalking and disorders of initiation and maintenance of sleep) was based on the criteria laid down in the International Classification of Sleep Disorders-Diagnostic and Scoring manual. ${ }^{20}$

\section{Statistical Methods}

All the data analysis was performed using statistical software SPSS 11.0, Chi-square test and t-test were used to determine significance of correlation and testing the differences in the prevalence's by characteristics.

\section{Results}

The overall prevalence of various sleep disorder depicted in Table 1.

Indian Journal of Sleep Medicine (IJSM), Vol. 3, No. 4, 2008
Table 1: Overall prevalence of sleep disorders amongst adults in the community

\begin{tabular}{|l|l|r|r|r|}
\hline S. & \multicolumn{1}{|c|}{ Sleep Disorder } & \multicolumn{3}{|c|}{ Prevalance } \\
\cline { 3 - 5 } No & & Total & Male & Female \\
\hline 1 & Snoring & 39.5 & 49.5 & 29 \\
\hline 2 & Habitual snoring & 28.2 & 33.4 & 21.3 \\
\hline 3 & Sleep-disordered breathing (SDB) & 4.3 & 4.8 & 3.8 \\
\hline 5 & Excessive daytime sleepiness (EDS) & 48.6 & 45.0 & 50.5 \\
\hline 6 & $\begin{array}{l}\text { Disorders of initiation \& } \\
\text { maintenance of sleep (DIMS) }\end{array}$ & 28.1 & 23.6 & 32.5 \\
\hline 7 & Sleep walking & 6 & 5.1 & 6.4 \\
\hline 8 & Nightmare & 30.6 & 24.0 & 36.5 \\
\hline 9 & Bruxism & 9.2 & 10.7 & 8.1 \\
\hline 10 & Restless legs syndrome (RLS) & 8.2 & 6.7 & 9.1 \\
\hline 11 & Sleeping pills consumption & 2.3 & 2.2 & 3.5 \\
\hline 12 & Accidents & 10.7 & 13.8 & 7.5 \\
\hline 13 & Any sleep disorder & $55 \%$ & & \\
\hline
\end{tabular}

Table 2: Snoring and its correlates

\begin{tabular}{|c|c|c|c|c|c|}
\hline \multicolumn{6}{|c|}{ Snoring and its correlates (39.5) } \\
\hline & & & & & P value \\
\hline BMI & \begin{tabular}{|l|}
$<18.5$ \\
$30.4 \%$
\end{tabular} & $\begin{array}{c}(18.5-24.9) \\
39.0 \%\end{array}$ & $\begin{array}{c}(25-29.9) \\
48.4 \%\end{array}$ & $\begin{array}{l}(>=30) \\
446 \%\end{array}$ & 01 \\
\hline SES & $\begin{array}{l}\text { Low } \\
(34.5 \%)\end{array}$ & \multicolumn{2}{|c|}{$\begin{array}{l}\text { High } \\
(41.1)\end{array}$} & & 0.055 \\
\hline Sex & $\begin{array}{l}\text { Male } \\
(49.5 \%)\end{array}$ & \multicolumn{2}{|c|}{$\begin{array}{l}\text { Female } \\
(29 \%)\end{array}$} & & 0.000 \\
\hline $\begin{array}{l}\text { Age } \\
0.002\end{array}$ & $\begin{array}{c}<31 \\
(28.4 \%)\end{array}$ & $\begin{array}{c}31-40 \\
(47.0 \%)\end{array}$ & $\begin{array}{l}>40 \\
(36.5)\end{array}$ & & 0.002 \\
\hline $\begin{array}{l}\text { Excessive Day } \\
\text { Time Sleeping }\end{array}$ & $\begin{array}{c}\text { Yes } \\
(35.9)\end{array}$ & $\begin{array}{c}\text { No } \\
(42.3)\end{array}$ & & & 0.039 \\
\hline
\end{tabular}

\section{Snoring}

The overall prevalence of snoring was found to be $39.5 \%$ (Males $=49.5 \%$, Females $=29 \%$ ). It correlated positively with body mass index (BMI) $(\mathrm{p}<0.01)$, age $(\mathrm{p}<0.002)$, sleep-disordered breathing ( $\mathrm{SDB})$, rising socio-economic strata $(\mathrm{p}<0.055)$ and excessive daytime sleepiness $(\mathrm{p}<0.039)$. Male gender was significantly associated with a high prevalence of snoring $(\mathrm{p}=0.000)$. (Table 2). Habitual snoring was found to be prevalent in $28.2 \%$ subjects. (Table 3 ). It was again found to correlate with rising socio-economic strata $(\mathrm{p}<0.026)$ and male gender. 
Table3 : Prevalence of habitual snoring and its correlates

\begin{tabular}{|l|c|c|c|c|c|}
\hline \multicolumn{7}{|l|}{ Habitual snoring $(28.2 \%)$} & Pvalue \\
\hline \multicolumn{7}{|c|}{ BMI } & $<18.5$ & $(18.5-24.9)$ & $(25-29.9)$ & $(>=30)$ & \\
& $21.8 \%$ & $28.6 \%$ & $30.8 \%$ & $30.4 \%$ & .325 \\
\hline SES & Low & High & & & \\
& $(22.5 \%)$ & $(30.1 \%)$ & & & 0.026 \\
\hline Sex & Male & $\begin{array}{c}\text { Female } \\
(21.3 \%)\end{array}$ & & & \\
& $(33.4 \%)$ & & & .000 \\
\hline Age & $<31$ & $31-40$ & $>40$ & & \\
& $(23.6 \%)$ & $(27.3 \%)$ & $(31.0 \%)$ & & .379 \\
\hline
\end{tabular}

\section{Sleep Disordered Breathing (SDB)}

The overall prevalence of SDB was 4.3\% (Table 4). It was significantly higher in males.

Table 4: Sleep disordered breathing and its correlates

\begin{tabular}{|c|c|c|c|c|c|}
\hline \multicolumn{6}{|c|}{ Sleep Disordered Breathing $4.3 \%$} \\
\hline & & & & & Pvalue \\
\hline \multirow[t]{2}{*}{ BMI } & $<18.5$ & $(18.5-24.9)$ & $(25-29.9)$ & $(>30)$ & \\
\hline & $3.6 \%$ & $4.0 \%$ & $5.7 \%$ & $6.0 \%$ & 0.113 \\
\hline SES & 4.3 (Low) & 4.2 (High) & & & 0.512 \\
\hline Sex & $\begin{array}{c}\text { Male } \\
(5.0 \%)\end{array}$ & $\begin{array}{l}\text { Female } \\
(3.6 \%)\end{array}$ & & & 0.022 \\
\hline Age & $<31(3.4)$ & $31-40(4.2)$ & $>40(5.2)$ & & 0.194 \\
\hline
\end{tabular}

\section{Excessive daytime sleepiness}

Approximately $48.6 \%$ of the adult population was seen to suffer from excessive daytime sleepiness. It correlated significantly with male gender $(\mathrm{p}<0.053)$, decreasing age $(\mathrm{p}<0.016) \&$ lower socio-economic strata (Table 5).

Table 5: Excessive daytime sleepiness and its correlates

\begin{tabular}{|l|l|l|l|l|l|}
\hline \multicolumn{7}{|c|}{ Excessive Day Time Sleeping (48.6\%) } & P value \\
\hline \multirow{2}{|c|}{ BMI } & $\begin{array}{l}<18.5 \\
45.6 \%\end{array}$ & $\begin{array}{l}(18.5-24.9) \\
52.8 \%\end{array}$ & $\begin{array}{l}(25-29.9) \\
45.1 \%\end{array}$ & $\begin{array}{l}(>=30) \\
44.6 \%\end{array}$ & 0.233 \\
\hline \multirow{2}{*}{ SES } & $\begin{array}{l}\text { Low } \\
(74.3 \%)\end{array}$ & $\begin{array}{l}\text { High } \\
(38.5 \%)\end{array}$ & & & \\
\hline \multirow{2}{*}{ Sex } & $\begin{array}{l}\text { Male } \\
(45 \%)\end{array}$ & $\begin{array}{l}\text { Female } \\
(50.5 \%)\end{array}$ & & & 0.000 \\
\hline \multirow{2}{*}{ Age } & $\begin{array}{l}<31 \\
(56.7)\end{array}$ & $\begin{array}{l}3140 \\
(50.7)\end{array}$ & $\begin{array}{l}>40 \\
(42.5)\end{array}$ & & .053 \\
\hline
\end{tabular}

\section{Restless leg syndrome (RLS)}

The overall prevalence of symptoms suggestive of restless leg syndrome was $8.2 \%$ (Table 6). It was found to correlate significantly with BMI $(\mathrm{p}<0.006)$, rising age $(\mathrm{p}<0.001)$ and female gender $(\mathrm{p}<0.057)$

Table 6: Restless leg syndrome and its correlates

\begin{tabular}{|l|l|l|l|l|l|}
\hline \multicolumn{5}{|c|}{ RLS (8.2\%) } & P value \\
\hline \multirow{2}{|c|}{ BMI } & $\begin{array}{l}<18.5 \\
4.2 \%\end{array}$ & $\begin{array}{l}(18.5-24.9) \\
4.1 \%\end{array}$ & $\begin{array}{l}(25-29.9) \\
8.0 \%\end{array}$ & $\begin{array}{l}(>=30) \\
20.9 \%\end{array}$ & .006 \\
\hline \multirow{2}{*}{ SES } & $\begin{array}{l}\text { Low } \\
(6.5)\end{array}$ & $\begin{array}{l}\text { High } \\
(8.8)\end{array}$ & & & \\
\hline \multirow{2}{*}{ Sex } & $\begin{array}{l}\text { Male } \\
(6.7 \%)\end{array}$ & $\begin{array}{l}\text { Female } \\
(9.1 \%)\end{array}$ & & & 0.239 \\
\hline \multirow{2}{*}{ Age } & $\begin{array}{l}<31 \\
(4.4 \%)\end{array}$ & $\begin{array}{l}31-40 \\
(6.4 \%)\end{array}$ & $\begin{array}{l}>40 \\
(9.8 \%)\end{array}$ & & .057 \\
\hline
\end{tabular}

\section{Sleepwalking}

The overall prevalence of sleepwalking in the adult population studied was 6\% (Table 7). It was found to correlate negatively with increasing BMI $(\mathrm{p}<0.012)$ and age and positively with rising socio-economic strata.

Table 7: Sleepwalking and its correlates

\begin{tabular}{|c|c|c|c|c|c|}
\hline \multicolumn{5}{|c|}{ Sleep Walking (6\%) } & \multirow[b]{2}{*}{$\begin{array}{l}P \\
\text { value }\end{array}$} \\
\hline & & & & & \\
\hline & $<18.5$ & $(18.5-24.9)$ & $(25-29.9)$ & $(>=30)$ & \\
\hline BMI & $12.0 \%$ & $4.9 \%$ & $4.8 \%$ & $4.7 \%$ & .012 \\
\hline SES & $\begin{array}{l}\text { Low } \\
(1.9)\end{array}$ & $\begin{array}{l}\text { High } \\
\text { (7.6) }\end{array}$ & & & 0.000 \\
\hline Sex & $\begin{array}{l}\text { Male } \\
(5.1 \%)\end{array}$ & $\begin{array}{l}\text { Female } \\
(6.4 \%)\end{array}$ & & & .242 \\
\hline Age & $\begin{array}{l}<31 \\
(11.3 \%)\end{array}$ & $\begin{array}{l}31-40 \\
(5.0 \%)\end{array}$ & $\begin{array}{l}>40 \\
(5.9 \%)\end{array}$ & & .052 \\
\hline
\end{tabular}

\section{Nightmare}

The prevalence of nightmares in the adult population studied was $30.6 \%$ (Table 8 ). It was found to correlate directly with lower socio-economic strata, female gender and inversely with age. However, no significant correlation was observed with BMI.

Indian Journal of Sleep Medicine (IJSM), Vol. 3, No. 4, 2008 
Table 8: Nightmare and its correlates

\begin{tabular}{|l|l|l|l|l|l|}
\hline \multicolumn{7}{|c|}{ Nightmare (30.6\%) } & P value \\
\hline \multicolumn{7}{|c|}{ BMI } & $\begin{array}{l}<18.5 \\
29.8 \%\end{array}$ & $\begin{array}{l}(18.5-24.9) \\
25.9 \%\end{array}$ & $\begin{array}{l}(25-29.9) \\
27.6 \%\end{array}$ & $\begin{array}{l}(>=30) \\
33.3 \%\end{array}$ & .628 \\
\hline \multirow{2}{*}{ SES } & $\begin{array}{l}\text { Low } \\
(35.8 \%)\end{array}$ & $\begin{array}{l}\text { High } \\
(28.8 \%)\end{array}$ & & & \\
\hline \multirow{2}{*}{ Sex } & $\begin{array}{l}\text { Male } \\
(24.0 \%)\end{array}$ & $\begin{array}{l}\text { Female } \\
(36.5 \%)\end{array}$ & & & 0.045 \\
\hline \multirow{2}{*}{ Age } & $\begin{array}{l}<31 \\
(50.6 \%)\end{array}$ & $\begin{array}{l}31-40 \\
(30.1 \%)\end{array}$ & $\begin{array}{l}>40 \\
(25.2 \%)\end{array}$ & & .000 \\
\hline
\end{tabular}

\section{Bruxism}

Bruxism was observed to be present in $9.2 \%$ of the adult population studied (Table 9). It correlated significantly with rising socio-economic strata $(\mathrm{p}<0.017)$ and snoring $(\mathrm{p}<0.002)$.

Table 9: Bruxism and its correlates

\begin{tabular}{|l|l|l|l|l|l|}
\hline \multicolumn{5}{|c|}{ Bruxism (9.2\%) } & P value \\
\hline \multirow{2}{|c|}{ BMI } & $\begin{array}{l}<18.5 \\
14.6 \%\end{array}$ & $\begin{array}{l}(18.5-24.9) \\
8.5 \%\end{array}$ & $\begin{array}{l}(25-29.9) \\
9.9 \%\end{array}$ & $\begin{array}{l}(>=30) \\
10.8 \%\end{array}$ & 0.236 \\
\hline \multirow{2}{*}{ SES } & $\begin{array}{l}\text { Low } \\
(5.9)\end{array}$ & $\begin{array}{l}\text { High } \\
(10.5)\end{array}$ & & & 0.017 \\
\hline \multirow{2}{*}{ Sex } & $\begin{array}{l}\text { Male } \\
(10.7 \%)\end{array}$ & $\begin{array}{l}\text { Female } \\
(8.1 \%)\end{array}$ & & & \\
\hline \multirow{2}{*}{ Age } & $\begin{array}{l}<1 \\
(11.3 \%)\end{array}$ & $\begin{array}{l}31-40 \\
(8.9 \%)\end{array}$ & $\begin{array}{l}>40 \\
(9.1 \%)\end{array}$ & & .713 \\
\hline \multirow{2}{*}{ Snoring } & $\begin{array}{l}\text { Yes } \\
(13.2 \%)\end{array}$ & $\begin{array}{l}\text { No } \\
(7.0 \%)\end{array}$ & & & .740 \\
\hline
\end{tabular}

\section{Consumption of sleeping pills}

Approximately $2.3 \%$ of the entire study population admitted that they consumed sleeping pills (Table10). Its use correlated with rising socio-economic strata $(\mathrm{p}<0.033)$ and symptoms suggestive of disorders of initiation and maintenance of sleep (DIMS) $(\mathrm{p}<0.072)$.

\section{Accidents}

Approximately $10.7 \%$ of the study population responded affirmatively to have met with road traffic accident in the past few years (Table 11). It correlated with rising socio-economic strata $(\mathrm{p}<0.004)$, male gender $(\mathrm{p}<0.05)$ and consumption of sleeping pills $(\mathrm{p}<0.002)$.

Indian Journal of Sleep Medicine (IJSM), Vol. 3, No. 4, 2008
Table10: Consumption of sleeping pills and its correlates

\begin{tabular}{|l|l|l|l|l|l|}
\hline \multicolumn{5}{|c|}{ Sleeping Pills (2.3\%) } \\
\hline \multicolumn{5}{|c|}{ P value } \\
\hline \multirow{2}{|c|}{ BMI } & $\begin{array}{l}<18.5 \\
1.5 \%\end{array}$ & $\begin{array}{l}(18.5-24.9) \\
3.4 \%\end{array}$ & $\begin{array}{l}(25-29.9) \\
4.6 \%\end{array}$ & $\begin{array}{l}(>=30) \\
1.1 \%\end{array}$ & 0.059 \\
\hline SES & $\begin{array}{l}\text { Low } \\
(1.2 \%)\end{array}$ & $\begin{array}{l}\text { High } \\
(2.8)\end{array}$ & & & \\
\hline Sex & $\begin{array}{l}\text { Male } \\
(2.2 \%)\end{array}$ & $\begin{array}{l}\text { Female } \\
(3.5 \%)\end{array}$ & & & $\begin{array}{l}.849 \\
(\text { ask TA) }\end{array}$ \\
\hline Age & $\begin{array}{l}<31 \\
(2.1 \%)\end{array}$ & $\begin{array}{l}31-40 \\
(4.1 \%)\end{array}$ & $\begin{array}{l}>40 \\
(2.2 \%)\end{array}$ & & .216 \\
\hline $\begin{array}{l}\text { Sleep } \\
\text { deprivation }\end{array}$ & $\begin{array}{l}\text { Yes } \\
(2.3 \%)\end{array}$ & $\begin{array}{l}\text { No } \\
(1.3 \%)\end{array}$ & & & .363 \\
\hline Snoring & $\begin{array}{l}\text { Yes } \\
(2.6 \%)\end{array}$ & $\begin{array}{l}\text { No } \\
(2.2 \%)\end{array}$ & & & .519 \\
\hline $\begin{array}{l}\text { Disorders of } \\
\text { initiation \& } \\
\text { maintenance of } \\
\text { sleep (DIMS) }\end{array}$ & $\begin{array}{l}\text { Yes } \\
(4.4 \%)\end{array}$ & $\begin{array}{l}\text { No } \\
(2.4 \%)\end{array}$ & & & \\
\hline
\end{tabular}

Table11: Prevalence of road traffic accidents and its correlates

\begin{tabular}{|c|c|c|c|c|c|}
\hline \multicolumn{6}{|c|}{ Accidents $(10.7 \%)$} \\
\hline & & & & & $P$ value \\
\hline BMI & $\begin{array}{l}<18.5 \\
5.1 \%\end{array}$ & $\begin{array}{l}(18.5-24.9) \\
11.7 \%\end{array}$ & $\begin{array}{l}(25-29.9) \\
11.7 \%\end{array}$ & $\begin{array}{l}(>=30) \\
16.9 \%\end{array}$ & 0.031 \\
\hline SES & $\begin{array}{l}\text { Low } \\
(6.3)\end{array}$ & $\begin{array}{l}\text { High } \\
(12.4)\end{array}$ & & & 0.004 \\
\hline Sex & $\begin{array}{l}\text { Male } \\
(\mathbf{1 3 . 8 \%})\end{array}$ & $\begin{array}{l}\text { Female } \\
(7.5 \%)\end{array}$ & & & .05 \\
\hline Age & $\begin{array}{l}<31 \\
(10.3 \%)\end{array}$ & $\begin{array}{l}31-40 \\
(11.1 \%)\end{array}$ & $\begin{array}{l}>40 \\
(10.0 \%)\end{array}$ & & .874 \\
\hline Sleeping pills & $\begin{array}{l}\text { Yes } \\
(30.0 \%)\end{array}$ & $\begin{array}{l}\text { No } \\
(10.0 \%)\end{array}$ & & & .002 \\
\hline SDB & $\begin{array}{l}\text { Yes } \\
(10.4 \%)\end{array}$ & $\begin{array}{l}\text { No } \\
(14.9 \%)\end{array}$ & & & .223 \\
\hline $\begin{array}{l}\text { Sleep } \\
\text { deprivation }\end{array}$ & $\begin{array}{l}\text { Yes } \\
(7.7 \%)\end{array}$ & $\begin{array}{l}\text { No } \\
(10.8 \%)\end{array}$ & & & .291 \\
\hline Snoring & $\begin{array}{l}\text { Yes } \\
(12.9 \%)\end{array}$ & $\begin{array}{l}\text { No } \\
(8.8 \%)\end{array}$ & & & .155 \\
\hline
\end{tabular}

\section{Disorders of initiation and maintenance of sleep}

Approximately $28.1 \%$ of the adult population was observed to have complaints suggestive of disorders of initiation and maintenance of sleep. It was found to correlate directly with female gender $(\mathrm{p}<0.003)$ and sleep deprivation $(\mathrm{p}<0.001)$ and inversely with rising age $(\mathrm{p}<0.048)($ Table12). 
Table 12: Prevalence of disorders of initiation $\&$ maintenance of sleep (DIMS) and its correlates

\begin{tabular}{|l|l|l|l|l|l|}
\hline \multicolumn{5}{|c|}{ Disorders of initiation \& maintenance of sleep (DIMS) (28.1\%) } \\
\hline \multicolumn{5}{|l|}{} & $\begin{array}{l}\text { P } \\
\text { value }\end{array}$ \\
\hline \multirow{2}{|c|}{ BMI } & $\begin{array}{l}<18.5 \\
28.7 \%\end{array}$ & $\begin{array}{l}(18.5-24.9) \\
29.3 \%\end{array}$ & $\begin{array}{l}(25-29.9) \\
29.4 \%\end{array}$ & $\begin{array}{l}(>-30) \\
22.1 \%\end{array}$ & 0.633 \\
\hline \multirow{2}{*}{ SES } & $\begin{array}{l}\text { Low } \\
(25.3 \%)\end{array}$ & $\begin{array}{l}\text { High } \\
(29.1 \%)\end{array}$ & & & 0.163 \\
\hline \multirow{2}{*}{ Sex } & $\begin{array}{l}\text { Male } \\
(23.6 \%)\end{array}$ & $\begin{array}{l}\text { Female } \\
(32.5 \%)\end{array}$ & & & \\
\hline \multirow{2}{*}{ Age } & $\begin{array}{l}<1 \\
(38.4 \%)\end{array}$ & $\begin{array}{l}31-40 \\
(28.3 \%)\end{array}$ & $\begin{array}{l}>40 \\
(24.8 \%)\end{array}$ & & .048 \\
\hline $\begin{array}{l}\text { Sleep } \\
\text { deprivation }\end{array}$ & $\begin{array}{l}\text { Yes } \\
(26.6 \%)\end{array}$ & $\begin{array}{l}\text { No } \\
(16.9 \%)\end{array}$ & & & .001 \\
\hline
\end{tabular}

\section{Sleep deprivation}

The prevalence of sleep deprivation with and without EDS is outlined in Table 13 Approximately more than half the population under study was observed to be sleepdeprived (sleep time $<8$ hours per day); and 29.3\% of them slept for less than seven hours. About one-fourth of the population $(26 \%)$ that slept for less than eight hours per day had perceptible symptoms of excessive daytime sleepiness (EDS) (Table 13)

Table 13: Prevalence of sleep deprivation

\begin{tabular}{|c|c|c|}
\hline \multicolumn{3}{|c|}{ Sleep deprivation with and with out EDS (prevalence) } \\
\hline & Overall (\%) & With EDS (\%) \\
\hline$<8 \mathrm{hrs}$ & 55.7 & 26.0 \\
$<7 \mathrm{hrs}$ & 29.3 & 14.3 \\
$<6 \mathrm{hrs}$ & 6.9 & 3.3 \\
\hline$<5 \mathrm{hrs}$ & 2.0 & 0.8 \\
\hline
\end{tabular}

\section{Discussion}

Epidemiology of sleep disorders in the general population has been a subject that has generated immense interest ever since major sleep disorders were initially described. Prevalence of sleep disorders in general and that of specific sleep disorders, in particular, has been found to be variable in different parts of the globe, amongst various age groups of the population and has often been observed to have definite patterns of distribution based on gender, socio-economic status and several other factors. The prevalence of sleep disorders would, logically depend to a large extent on the specific validated instrument that has been used to determine it.

\section{Snoring}

The overall prevalence of snoring was found to be $39.5 \%$ (Males $=49.5 \%$, Females $=29 \%$ ) in the present study. Habitual snoring was reported to be present in $28.2 \%$ in the present study.In a cross sectional survey of 370 adults living in Nigeria, the overall presence of snoring was $31.6 \%$, habitual snoring (14\%) and moderate snoring $(17 \%)^{4}$. It was significantly associated with male sex, old age, increased BMI and cigarette smoking. The severity of snoring was also associated with a higher ESS score, daytime symptoms and other co morbidities. A retrospective analysis conducted at two dental practices, using questionnaire responses obtained from 175 men and 156 women, $46 \%$ of the men and $19 \%$ of the women reported snoring frequently or always 5 . Over $80 \%$ of Australian middle aged men have been reported to snore for more than $10 \%$ of the night ${ }^{6,7}$. Habitual snoring was reported by $23 \%$ of a cohort of 784 Chinese middleaged male office-workers in a questionnaire-based survey $^{8}$. In another study of 658 healthy urban Indian males coming to the hospital for routine health checkup, $26 \%$ were observed to be snorers ${ }^{9}$. About $20 \%$ of the middle-aged population are reported to snore each night. ${ }^{34}$ In the present study, snoring was more common amongst males, those with a higher BMI and rising socioeconomic strata as was found in other studies. It was much lower than those found in Caucasians, and is comparable to that in Chinese and is higher than that reported in African populations. The possible causes of this difference could be due to differences in BMI and cranio-facial features between these races.

\section{Sleep-disordered breathing (SDB)}

Obstructive sleep apnea (OSA) with daytime impairment, that is, OSA syndrome, is estimated to occur in 1 out of 20 adults; minimally symptomatic or asymptomatic OSA is estimated to occur in $24 \%$ of the population. ${ }^{10}$. Twentyfive percent of middle aged men and $10 \%$ of women in Australia have OSA, defined as more than 5 obstructed breathing events per hour of sleep ${ }^{12,7}$. In a questionnairebased study of 402 adults in the Netherlands, $5.7 \%$ had complaints pertaining to apnea ${ }^{11}$. Apnea was reported in about $2 \%$ of the respondents while the presence of clinically suspected OSA (CSOSA) was 1\% (1.9\% in males and $0.5 \%$ in females) in the Nigerian study ${ }^{4}$. Based on a validated questionnaire, $33 \%$ of the men and $6 \%$ of the women attending a dental clinic were predicted to have moderate or severe sleep apnea ${ }^{5}$. Epidemiological

Indian Journal of Sleep Medicine (IJSM), Vol. 3, No. 4, 2008 
studies, in general, have revealed a prevalence of SDB of up to $20 \%$ and that of OSAS of $4-5 \%$ of middle aged population ${ }^{13}$. The prevalence of OSA in the present study was found to be $4.3 \%$. It may be added that most studies globally, who have reported the prevalence of SDB have based their observation on the Apnea Hypopnea Index (AHI). However, in the present study, the prevalence is based on the Respiratory Distress Index (RDI) which includes apneas, hypopneas and respiratory effort related arousals (RERA). Also, since the study population is not very large, the actual prevalence in the community at large may be even higher than this figure. A meta-analysis of 12 studies of OSA prevalence in Western populations estimated that 1 to $5 \%$ of adult men have OSA syndrome (i.e. frequent apnea and hypopnea episodes and daytime sleepiness) ${ }^{27}$ Another meta-analysis of nine studies, that used two-stage sampling procedures in which sleep studies were conducted on subsets of participants drawn from large sample surveys, observed the prevalence of undiagnosed OSA syndrome to range from 0.3 to $5 \% .{ }^{28}$ From a survey sample of Hong Kong men, 30 to 60 years of age, Ip and colleagues estimated the prevalence of OSA (defined as an AHI of 5 or more plus excessive daytime sleepiness) to be $4 \% .^{8}$ Obesity, a strong risk factor for OSA, is commoner in white populations than in Asian countries. Ip and colleagues also observed that correlations between BMI (and other measures of body habitus) and prevalence of OSA were weaker in the Hong Kong study than those seen in studies of white subjects ${ }^{8}$ A possible explanation provided by the authors was that other strong risk factors for OSA (such as cranio-facial features that compromise the upper airway that are more prevalent in the Chinese relative to Western population) must exist. In the present study as well, it was seen that the prevalence of SDB in the underweight BMI group $(<18.5)$ was $3.6 \%$ and that in the normal BMI group (18.5-24.9) was $4 \%$ (Table 4). This is an important observation which also points towards factors other than increased BMI that determine the prevalence of SDB in this population. These risk factors may also explain the nearly similar prevalence of OSA in the Indian population, as observed in this study, and the Western studies. High BMI (and a body habitus favoring OSA) is also less prevalent amongst Indians as compared to the Western population. Thus, perhaps, two different phenotypes of OSA may exist; one with an increased BMI and the other with cranio-facial features conducive to the occurrence of OSA but with a normal BMI. The proportion of the latter phenotype may predominate in
Asian countries, as evidenced by observations from China as well as in the present study.

The gender distribution of OSA as observed in this study is similar to that in the other studies. A slightly higher proportion of females were found in this study, probably because the parameter studied here was RDI instead of AHI (the latter was used in most other studies). It may be appreciated that a large number of female subjects with UARS (which manifests in the PSG study as RERA and is commoner in females) might have been missed in other studies which utilized AHI as the parameter to assess the prevalence of SDB.

The trends of OSA prevalence in relation to age were also similar in the present study as compared to observations by other authors from the western hemisphere.

\section{Restless Legs Syndrome (RLS)}

In a community-based survey in a rural area of Japan, using the NIH/International RLS study Group Consensus questionnaire followed by telephone interview, it was observed that $1.8 \%$ subjects were judged as RLSpositive $^{14}$. The prevalence of RLS in adult Japanese population is lower than that reported in Caucasian populations. In this study multiple logistic regression analysis revealed that the existence of RLS was significantly associated with depression, lowered mental quality of life, and sleep disturbances. In the questionnaire survey conducted in the Netherlands, prevalence of RLS/periodic leg movement disorder was $5.2 \%{ }^{11}$. The overall global prevalence of RLS has been reported to be approximately $10 \% .^{21}$ The overall prevalence of symptoms suggestive of restless leg syndrome was $8.2 \%$ in the present study (Table 6). The prevalence of symptoms suggestive of RLS in the present study was quite similar to the global prevalence. It also correlated with female gender and age. ${ }^{21,29-31}$

\section{Excessive daytime sleepiness (EDS)}

EDS is a principal feature of OSA syndrome. Many details of the association between sleepiness and OSA in the general population are ill-understood; however both OSA and non-apneic snoring are important causes of daytime sleepiness ${ }^{10}$. Since snoring is a strong marker of OSA, the correlation of snoring with EDS might be due to their joint association; many studies, however, 
suggest that snoring is independently associated with $\mathrm{EDS}^{18}$. Habitually snoring subjects with an AHI less than 5 in the Wisconsin Sleep Cohort Study had a 3fold increased odds of experiencing multiple motor vehicle accidents during a 5-year period compared with subjects without habitual snoring ${ }^{15}$. Hypersomnia was found in $2 \%$ in the general population questionnaire. Survey in the Netherlands ${ }^{11}$. Daytime hypersomnolence was found in $22 \%$ of the study population in another Indian study ${ }^{9}$. The mean Epworth score of snorers was $8.39 \pm 4.67$ and that of non-snorers was $6.05 \pm 3.67$ in the same study. The severity of snoring was also associated with higher ESS score and daytime symptoms in the Nigerian study ${ }^{4}$. In another questionnaire based study conducted amongst out-patients in a family medicine clinic in Thailand, $19.5 \%$ of the patients reported sleepiness ${ }^{16}$. In a cohort of older drivers, 19\% subjects had an abnormal ESS of $\geq 10^{17}$. About $23 \%$ of the study cohort of a general community was associated with $\mathrm{EDS}^{8}$. Approximately $48.6 \%$ of the adult population was seen to suffer from excessive daytime sleepiness in the present study.

An important cause of EDS is sleep deprivation. In the present study, a negative correlation was observed between EDS and increasing age. One of the factors responsible for this observation could be the presence of significant sleep deprivation, which is found more commonly in the younger age group. Also, the problem of EDS was more common in the female gender; this may be due to the multi-faceted social role played by the women or due to hormonal influences. The higher prevalence of EDS in the lower socio-economic strata may be explained on the basis of poor living conditions which may be detrimental to sleep quality. Also, the high prevalence of EDS in the study population points towards other determinants like depression, sleep deprivation (due to socio-economic and cultural factors) and disorders of initiation and maintenance of sleep and various other factors.

\section{Sleepwalking}

The overall prevalence of symptoms of sleepwalking in the adult population studied was $6 \%$ in this study. Sleepwalking has a heritable predisposition and occurs in $1 \%$ to $15 \%$ of the general population. ${ }^{21}$ It is more common in children than in adults, and it is not very common to find sleepwalking starting in adults who never had it in their childhood. ${ }^{32}$ Recent studies have suggested that adult sleepwalkers may have a distinctive personality profile. ${ }^{32}$ In this study, symptoms of sleepwalking were observed to be more prevalent in underweight subjects.

\section{Bruxism}

The prevalence of sleep bruxism with grinding in adult population has been reported to be about $10 \% .{ }^{22}$ Nocturnal bruxism is common (from $5 \%$ to $20 \%$ of the population) and the etiology is unknown. ${ }^{33}$ The prevalence of symptoms suggestive of bruxism in the present study was $9.2 \%$.

\section{Disorders of initiation and maintenance of sleep (DIMS)}

In most studies, about 32 to 40 percent of adults have been reported to experience one or more symptoms of insomnia over periods ranging from past 30 days to 12 months. ${ }^{24}$ Using more restricted definitions, the prevalence of insomnia has been found to range from $10 \%$ to $17 \% .^{24}$ Thirty percent of the population has been reported to have insomnia in one year; one-third says that the problem is severe. ${ }^{31}$ Eighty percent of the cases of insomnia seen in general practice is related to anxiety and depression; half of the cases of insomnia in specialized clinics are ascribed to psychological causes, drugs and alcohol. ${ }^{32}$ The only general population study, using DSM IV criteria, found the past 30 days prevalence of insomnia among subjects hailing from five different countries to vary from $4.4 \%$ to $6 \%{ }^{24}$ In the present study, $28 \%$ of the subjects had experienced some symptoms of either initiation or maintenance of sleep in the past 12 months. This indicates a huge burden of the untreated problem in the general population.

\section{Consumption of sleeping pills}

The consumption of sedatives and sleeping pills has been determined to be approximately $12 \%$ in the general population. ${ }^{26}$ An increase in the prescription and use of hypnotic drugs has been observed with increasing age ${ }^{35}$ In the present study, $2.3 \%$ of the study population was found to consume sleeping pills. The consumption of sleeping pills was more frequent amongst female subjects, those with DIMS and amongst those belonging to the higher socio-economic strata (Table 10). Also, a changing pattern of consumption of such medication was observed in younger individuals as well as those from higher socioeconomic strata.

Indian Journal of Sleep Medicine (IJSM), Vol. 3, No. 4, 2008 


\section{Accidents}

According to the population studied and the methods adopted, the frequencies of sleep-related or fatigue-related accidents vary between 1 and $25 \% .{ }^{25}$ Sixteen percent of road accidents and $20 \%$ of highway accidents are known to be related to sleepiness at the wheel ${ }^{25}$ Studies reveal that $20 \%$ of all drivers have fallen asleep behind the wheel at least once; one-third of heavy trucking accidents which result in the driver being killed is attributed to fatigue. ${ }^{32}$ In a questionnaire based survey of Norwegian drivers, sleep or drowsiness was a contributing factor in $3.9 \%$ of all accidents. ${ }^{25}$ In the present study, about $10.7 \%$ of the subjects were found to have met with an accident in the past few years. The prevalence of accidents in the general population was found to be very high. It strongly correlated with consumption of sleeping pills and rising social strata. Many of these accidents could have been due to sleep related disorders such as SDB (OSA) and sleep deprivation.

\section{Nightmare}

Nightmares, which are REM sleep parasomnias, have been reported to occur at least once a week in approximately $5 \%$ of the adult population. ${ }^{23}$ Fifty percent of adults have occasional nightmares and 1\% frequent nightmares ( $\geq 1$ a week). ${ }^{32}$ The prevalence of nightmares in the adult population in the present study was $30.6 \%$.

\section{Sleep deprivation}

Several factors that may be responsible for sleep deprivation have been traditionally identified. They include conditions like poor sleep hygiene, improper sleeping environment, and illness, work (shift work and frequent traveling), other sleep disorders (sleep apnea, PLMS and snoring), medications, personal choice, parenting of babies etc. The 2002 National Sleep Foundation Poll revealed that 39\% of American adults reported sleeping less than seven hours. ${ }^{36}$ In another study, one-fifth of the population was sleep-deprived. ${ }^{36}$ The prevalence of sleep deprivation in the industrialized world seems to be on the rise ${ }^{36}$ The estimated prevalence of sleep deprivation in the present study is also comparable to these figures. The changing socioeconomic and cultural profile of the urban Indian society is also reflected in these observations.

Indian Journal of Sleep Medicine (IJSM), Vol. 3, No. 4, 2008

\section{Conclusion}

In this questionnaire-based survey, approximately 55\% of the study population was observed to have some type of sleep-related disorder (Table 1). This indicates that the impact of sleep disorders on the morbidity profile of this segment of urban society is of a gigantic proportion. It also reflects the phenomenal burden of undiagnosed sleep disorders in this segment of the general population as well as its impact on social, mental, physical and economic health of the society.

Much needs to be done in innovating ways and means to design cost-effective strategies suitable to screen the population and develop adequate manpower and infrastructure to treat these disorders. The task is humungous. Also, greater emphasis needs to be placed in training and education at various levels that include undergraduate \& postgraduate medical curricula, paramedical courses and nursing syllabi, as far as sleep medicine is concerned. There is ample scope for future research in this arena.

\section{References}

1. Suri JC, Sen MK, Adhikari T. Epidemiology of sleep disorder in school children of Delhi: A Questionnaire Based Study. Indian J Sleep Med 2008;3.2,42-50

2. Chervin R et al. Pediatric Sleep Questionnaire, University of Michigan (chervin@med.umich.edu)

3. Uliel S, Tauman R, Green field $M$ et al. Chest $2004 ; 125: 872-878$.

4. Adewole OO, Adeyemo H, Ayeni F, Anteyi EA, Ajuwon ZO, Erhabor GE, Adewole TT. Prevalence and correlates of snoring among adults in Nigeria: Afr Health Sci, $2008 ; 8(2): 108-13$.

5. Levendowski DJ, Morgan T, Montague J, Melzer V, Berka C, Westbrook PR. Prevalence of probable obstructive sleep apnea risk and severity in a population of dental patients. Sleep Breath, 2008;12(4):303-9.

6. Bearpark $\mathbf{H}$, Elliott $L$, Grunstein R, et al. Snoring and sleep apnea. A population study in Australian men. Am J Respir Crit Care Med 1995;151:1459-65.

7. Grunstein RR, Philips CL. Obstructive sleep apnoeagetting to the heart of the matter?. MJA, 2008;188(6): 324-25.

8. Ip MSM, Lam B, Lauder IJ, Tsang KWT, Chung K, Mok Y, Lam W. Community study of sleep-disordered breathing in middle-aged Chinese men in Hong Kong. Chest 2001; 119:62-69

9. Udwadia ZF, Doshi AV, Lonkar SG, Singh Cl. Prevalence of sleep-disordered breathing and sleep apnea in middleaged urban Indian men. Am J Respir Crit Care Med, 
$2004 ; 169: 168-73$.

10. Young T, Peppard PE, Gottlieb DJ. Epidemiology of obstructive sleep apnea - a population health perspective. Am J Respir Crit Care med, 2002;165:1217-39.

11. Spoormaker VI, Van den Bout J. The prevalence of sleep disorders in the Netherlands.

12. Young T, Peppard PE, Gottlieb DJ. Epidemiology of obstructive sleep apnea: a population health perspective. Am J Respir Crit Care Med, 2002;165:1217-39.

13. Jennum P, Riha RL. Epidemiology of sleep apnoea/ hypopnoea syndrome and sleep-disordered breathing. Eur Respir J 2009;33:907-914.

14. Nomura T, Inoue $Y$, Kusumi M, Uemura $Y$, Nakashima $K$. Prevalence of restless legs síndrome in a rural community in Japan. Mov Disord, 2008;23(16):2363-9.

15. Young TB, Blustein J, Finn L, Palta M. Sleep-disordered breathing and motor vehicle accidents in a population-based sample for employed adults. Sleep 1997;20:608-13.

16. Tubtimtes S, Sukying C, Prueksaritanond S. Sleep problems in out-patient of primary care unit. J Med Asoc Thai. $2009 ; 92(2): 273-8$

17. Vaz Fragoso CA, Araujo KL, Van Ness PH, Marottoli RA. Prevalence of sleep disturbances in a cohort of older drivers. J Gerontol A Biol Sci Med Sci, 2008;63(7):715-23.

18. Stradling JR, Crosby JH, Payne CD. Self reported snoring and daytime sleepiness in men aged $35-65$ years. Thorax $1991 ; 46: 807-810$.

19. Douglass AB, Bornstein R,Nino-Murcia G, Keenan S, Miles L, Zarcon VP Jr. the Sleep Disorders Questionnaire. I: Creation and multivariate structure of SDQ. Sleep $1994 ; 17: 160-7$

20. International Classification of sleep disorders.

21. Chokroverty S, Hening W, Walters A, Allen R. Restless legs syndrome-Introduction.In Chokroverty S, Hening W, Walters A(eds):Sleep and Movement disorders. Philadelphia, PA, Butterworth Heinemann, 2003, p 312-15.

22. Lavigne GJ, Montplasir JY. Restless legs syndrome and sleep bruxism: prevalence and association among Canadians. Sleep 1994;17:739

23. Chokroverty S, Hening w, Walters A, Allen R. An approach to a patient with movement disorders during sleep and classification..In Chokroverty S, Hening W, Walters
A(eds):Sleep and Movement disorders. Philadelphia, PA, Butterworth Heinemann, 2003, p 201-18.

24. Johnson EO. Epidemiology of insomnia from adolescence to old age. Sleep Med Clin 2006; 1:305-17.

25. Phillip $\mathbf{P}$, Taillard J.Driving performance. In Lenfant $C$, Kushida CA (eds) Sleep Deprivation. Lung Biology in Health and Disease Series; 193:262-267

26. Bodonada MA, Cid-Ruzafa j.Drugs and alcohol use in Spain: consumption habits, attitudes and opinions. Public health $1997 ; 111: 277-84$

27. Davies RJO, Stradling JR. The epidemiology of sleep apnea. Thorax 1996;51:S65-S70.

28. Lindberg E, Gisalson T. epidemiology of sleep-related obstructive breathing. Sleep Med Rev 2000;4:411-433.

29. Purvis C, Phillips B, Asher K et al. The 1996 Kentucky behavioral risk factor surveillance survey. Sleep Res $1997 ; 26: 474$ (abstr)

30. Ulfberg i, Nystrom B, Carter N, Edling C. Prevalence of restless legs syndrome among men aged 18 to 64 years An association with somatic disease and neuropsychiatric symptoms. Mov Disord 2001;16;1159

31. RLS Medical bulletin. Rochester MN, Restless Leg Syndrome Foundation, 1999:1

32. Shapiro CM, Dement W. Impact and epidemiology of sleep disorders. In Shapiro CM (ed): ABC of Sleep Disorders London, BMJ Publishing Group, 1993, p1-4

33. Driver HS, Shapiro CM. Impact and epidemiology of sleep disorders. In Shapiro CM (ed): ABC of Sleep Disorders; London, BMJ Publishing Group, 1993, p26-29

34. Douglas NJ. The sleep apnoea/hypopnoea syndrome and snoring. In Shapiro CM (ed): ABC of Sleep Disorders London, BMJ Publishing Group, 1993,p19-22 Driver HS, Shapiro CM. Impact and epidemiology of sleep disorders. In Shapiro CM (ed): ABC of Sleep Disorders; London, BMJ Publishing Group,1993, p26-2

35. Swift CG, Shapiro CM. Sleep and sleep problems in elderly people. In Shapiro CM (ed): ABC of Sleep Disorders; London, BMJ Publishing Group,1993, p37-40.

36. Kaplan J. Sleep Deprivation .In Butkov N, Lee-Chiong T (eds):Fundamentals of Sleep Technology; Lipincott, Williams \& Wilkins; American Association of Sleep Technologists, 2007 ; p 25. 